\title{
On linyphiid spiders of Myanmar, with the description of a new genus and species (Aranei: Linyphiidae)
}

\author{
О пауках-линифиидах из Мьянмы, с описанием нового рода \\ и вида (Aranei: Linyphiidae)
}

\author{
A.V. Tanasevitch \\ A.B. Танасевич \\ A.N. Severtsov Institute of Ecology and Evolution, Russian Academy of Sciences, Leninsky prospekt 33, Moscow 119071, Russia. \\ E-mail: tanasevitch@gmail.com \\ Институт проблем экологии и эволюции им. А.Н. Северцова РАН, Ленинский проспект 33, Москва 119071, Россия.
}

KEY WORDS: taxonomy, spiders, Arachnida, Erigoninae, southeastern Asia.

КЛЮЧЕВЫЕ СЛОВА: таксономия, пауки, Arachnida, Erigoninae, юго-восточная Азия.

\begin{abstract}
A new monotypic genus, Parvunaria gen.n., with $P$. birma sp.n. as the type species, is described from highlands of western Myanmar. The new genus is characterized by both embolus and radix being highly peculiar and tiny, while the convector highly sclerotized and well-developed. Habitually, the new genus is similar to Nasoona Locket, 1982 and Nasoonaria Wunderlich et Song, 1995, but differs clearly by the palpal conformation and chaetotaxy. A check-list of the linyphiid fauna of Myanmar is compiled, being also supplied with detailed localities and global distribution patterns.
\end{abstract}

How to cite this article: Tanasevitch A.V. 2018. On linyphiid spiders of Myanmar, with the description of a new genus and species (Aranei: Linyphiidae) // Arthropoda Selecta. Vol.27. No.2. P.172-176. doi: 10.15298/arthsel. 27.2.09

РЕЗЮМЕ. Новый монотипический род Parvunaria gen.n. с P. birma sp.n. в качестве типового вида описан из высокогорий западной Мьянмы. Род характеризуется чрезвычайно коротким эмболюсом и крошечным радиксом, а также крупным и сильно склеротизованным конвектором. Габитуально, новый род имеет черты сходства с Nasoona Locket, 1982 и Nasoonaria Wunderlich et Song, 1995, но отличается строением пальпы самца и хетотаксией. Приведён список видов фауны линифиид Мьянмы с подробным указанием мест сборов и распространением.

\section{Introduction}

The linyphiid fauna of Myanmar is known to comprise ten species only [World Spider Catalog, 2018], this being one of the lowest indices among the Southeast Asian countries. Three species from that short list, as well as the species described in this contribution are registered only from their type localities.

\section{Material and methods}

This paper is based on material kept at the Senckenberg Museum, Frankfurt on Main, Germany (SMF). Specimens preserved in $70 \%$ ethanol were studied using a MBS-9 stereo microscope and a Wild compound microscope. A Levenhuk C-800 digital camera was used for the execution of some drawings. Images of multiple focal sections were combined using Helicon Focus image stacking software. The chaetotaxy is given in a formula, i.e, 1.1.1.1, which refers to the number of dorsal spines on tibiae I-IV. The sequence of leg segment measurements is as follows: femur + patella + tibia + metatarsus + tarsus. All measurements are measured using an ocular micrometer and given in millimeters. Scale lines in the figures correspond to $0.1 \mathrm{~mm}$ unless indicated otherwise. The terminology of copulatory organs mainly follows that of Merrett [1963], Hormiga [2000], and Tanasevitch [1998; 2015].

The following abbreviations are used in the text and figures: a.s.l. - above sea level; $\mathrm{C}$ - convector sensu Tanasevitch [1998]; D — duct; DAC — distal apophysis of convector sensu Tanasevitch [2015]; DSA - distal suprategular apophysis sensu Hormiga [2000]; E\&R - embolus and radix; MM - median membrane; TmI — position of trichobothrium on metatarsus I.

Description

\section{Parvunaria gen.n.}

TYPE SPECIES: Parvunaria birma sp.n.

ETYMOLOGY. The generic name is a combination of two words: "parvus", meaning "small", refer- 

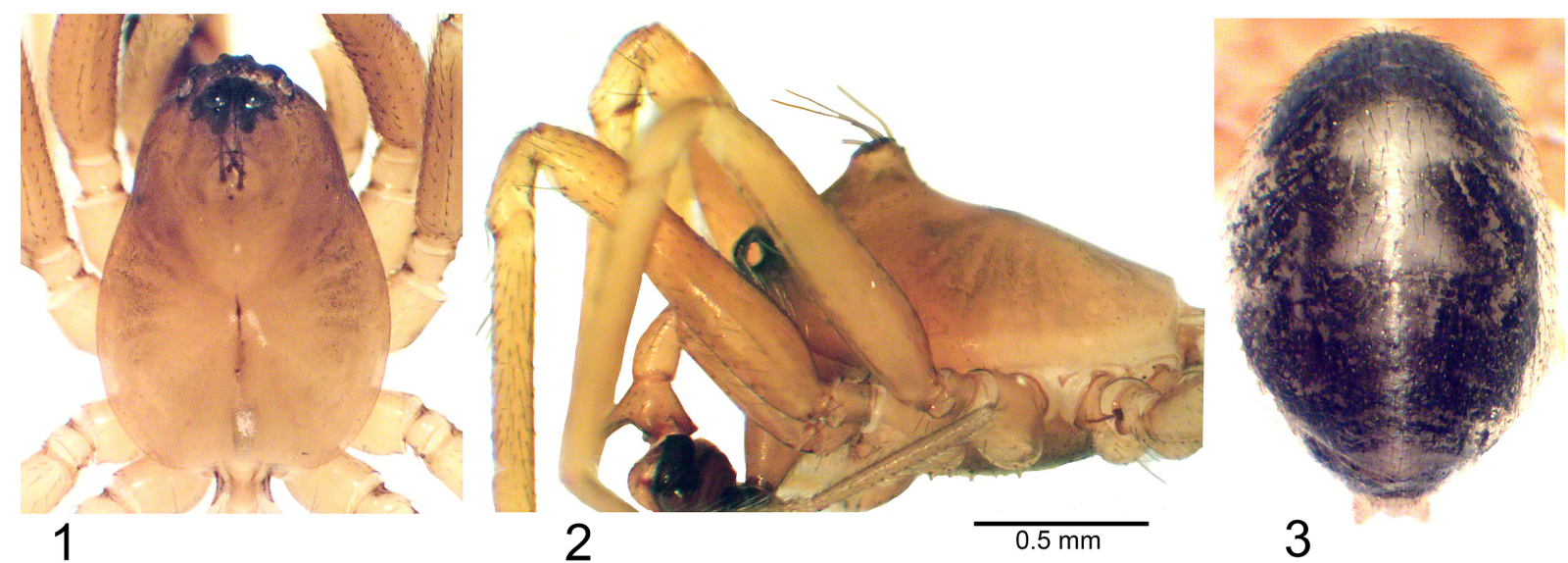

Figs 1-3. Photographs of Parvunaria birma gen.n., sp.n., $\sigma^{7}$ holotype. 1, 2 - prosoma, dorsal and lateral view, respectively; 3 abdomen, dorsal view.

Рис. 1-3. Фотографии Parvunaria birma gen.n., sp.n., голотип Оج. 1, 2 - головогрудь, вид сверху и сбоку, соответственно; 3 брюшко, вид сверху.

ring the extremely small size of the embolus, and " $\mathrm{Na}$ soonaria", meaning a habitual similarity of both genera. The gender is feminine.

DIAGNOSIS. The new genus belongs to the subfamily Erigoninae and is characterized by the following combination of characters, both somatic and genitalic:

1) relatively large-sized erigonines, total length ca $2.75 \mathrm{~mm}$;

2) male carapace modified (see Figs 1 \& 2);

3) chaetotaxy 1.1.1.1;

4) metatarsi I-III each with a trichobothrium;

5) TmI 0.66 ;

6) palpal tibia highly modified (see Figs 4-6);

7) embolus very small, radix reduced;

8 ) convector well-developed and highly sclerotized.

By the modified carapace and the shape of the palp, the new genus somewhat resembles Nasoona Locket, 1982 and Nasoonaria Wunderlich et Song, 1995. However, the similarity of the palp structure seems to be superficial, because the palpal conformation in Parvunaria gen.n. is actually very different. In contrast to the new genus, Nasoona and Nasoonaria show a long, mainly coiled embolus and a well-developed radix. In addition, the chaetotaxy formula in these two genera is 2.2.1.1, while a trichobothrium on each metatarsus IV is present, vs. 1.1.1.1 and no trichobothrium, respectively, in Parvunaria gen.n.

SPECIES INCLUDED. Only the type species.

DESCRIPTION. See below under species description.

DISTRIBUTION. Known only from the type locality in western Myanmar.

\section{Parvunaria birma sp.n.}

Figs 1-9.

HOLOTYPE O' (SMF), MYANMAR, south of Chin State, Nat Ma Taung National Park, road from Kanpetlet to Mindat, $21^{\circ} 13^{\prime}$ $13.2^{\prime \prime} \mathrm{N} 93^{\circ} 58^{\prime} 53.5^{\prime \prime} \mathrm{E}, 2381 \mathrm{~m}$ a.s.1., disturbed primary forest with bamboo and understory, leaf litter, sieving at day, 10.V.2014, leg. P. Jäger.

NAME. The specific name is a noun in apposition, referring to the country of origin, Myanmar (earlier Burma, Birma).

DESCRIPTION. $\sigma^{7}$ holotype. Total length 2.75 . Carapace modified as shown in Fig. 1 \& 2; 1.30 long, 0.93 wide, pale brown. Anterior part of carapace behind eyes with a conical elevation carrying several, strong, terminal spines directed forwards. Eyes normal, not enlarged. Chelicerae 0.45 long. Legs pale brown. Leg I 3.94 long $(1.13+0.33+0.93+0.95+0.60)$, IV 4.56 long $(1.25+0.35+1.13+1.23+0.60)$. Chaetotaxy 1.1.1.1. TmI 0.66. Metatarsus I-III each with a trichobothrium. Palp (Figs 4-9): Palpal tibia extending into a narrow, long, conical process ending with two small denticles. Paracymbium L-shaped, hooked apically, its distal part bearing several long spines. Distal suprategular apophysis strongly sclerotized, relatively long and wide, with a shallow hollow distally. Median membrane small, poorly visible. Radix very small, almost reduced, embolus very short, tooth-like. Convector massive, highly sclerotized, with a thick, sharp distal apophysis directed forwards. Abdomen 1.50 long, 1.00 wide, dorsal pattern as shown in Fig. 3.

Female unknown.

DISTRIBUTION. Known only from the type locality in western Myanmar.

The linyphiid spiders described or recorded from Myanmar

Bathyphantes paracymbialis Tanasevitch, 2014

DISTRIBUTION. The species has recently been described from Laos, Thailand, West Malaysia (Tanasevitch, 2014a), and later registered from Indonesia (Sumatra) [Tanasevitch, 2017]. In Myanmar, it known 


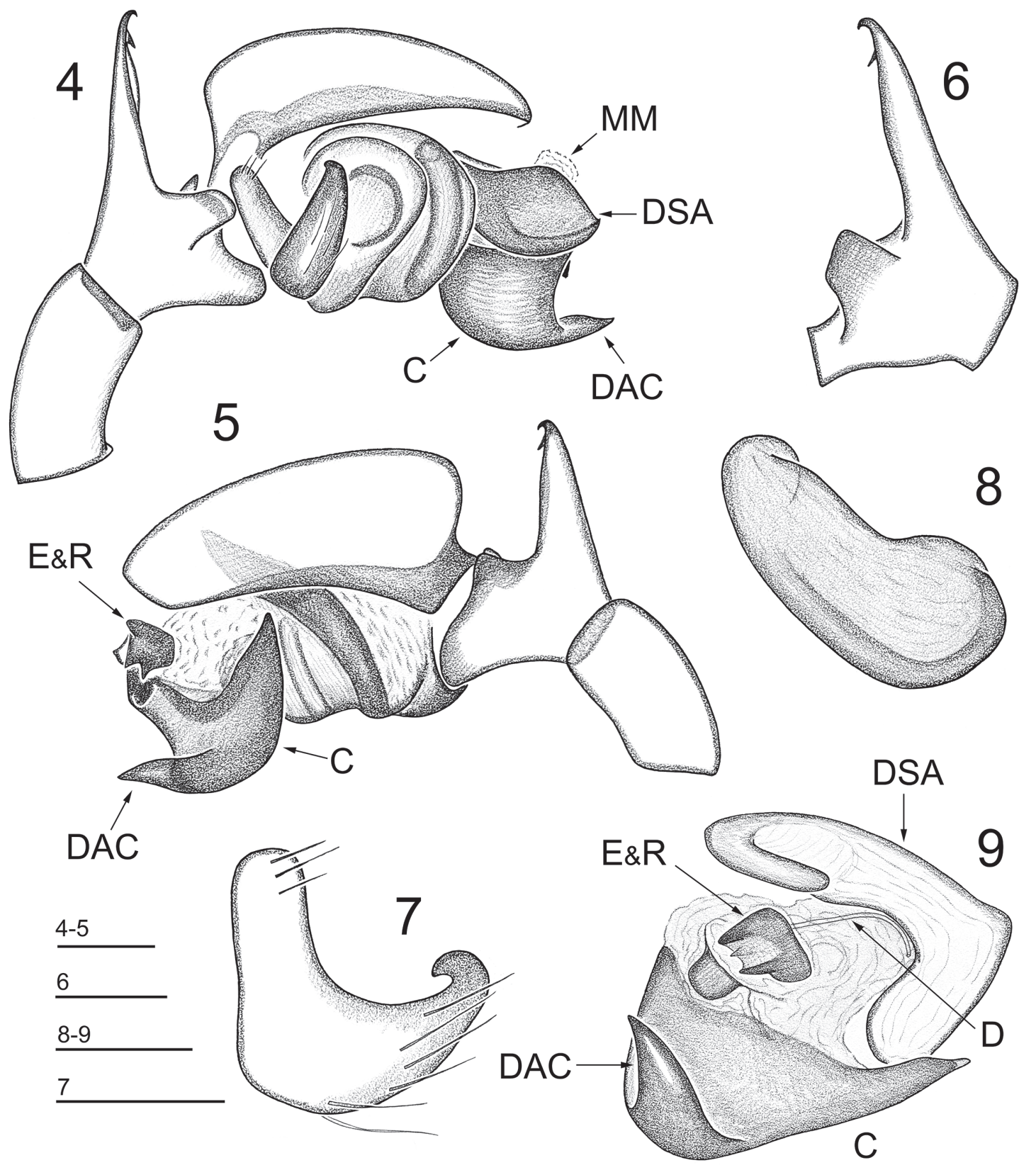

Figs 4-9. Parvunaria birma gen.n., sp.n., $0^{7}$ holotype. 4, 5 - right palp, retrolateral and prolateral view, respectively; 6 - palpal tibia, prolateral view; 7 - paracymbium; 8, distal suprategular apophysis; 9 - distal suprategular apophysis and embolic division.

Pис. 4-9. Parvunaria birma gen.n., sp.n., голотип O². 4, 5 - правая пальпа, ретролатерально и пролатерально, соответственно; 6 - голень пальпы, пролатерально; 7 - парацимбиум; 8 - дистальный супратегулярный отросток; 9 - дистальный супратегулярный отросток и эмболюсный отдел.

from the National Kandawgyi Botanical Gardens (1120 m a.s.1.), Mandalay Region [Tanasevitch, 2017].

\section{Hylyphantes graminicola (Sundevall, 1830)}

NOTES. Originally, the species has been described from Burma (= Myanmar) as Erigone birmanica Thorell, 1895 [Thorell, 1895]; later it was transferred to Hylyphantes Simon, 1884 by Tanasevitch [2010], and finally it has been synonymized with $H$. graminicola [Tanasevitch, 2014a].

DISTRIBUTION. Throughout the Palearctic: from Iceland eastward to Chukotka, from northern Siberia southward to Tian Shan; in the Far East: Kamchatka, Sakhalin, Japan, Korea, Taiwan [Tanasevitch, 2014a]. In The Oriental Asia: Vietnam [Tu, Li, 2005] and Laos [Tanasevitch, 2014a]. In Myanmar H. graminicola known from Tharrawaddy, Bago State [Thorell, 1895]. 
Ketambea acuta Tanasevitch, 2017

DISTRIBUTION. Known only from the type locality, Kampetlet (1716 m a.s.1.), Chin State, Myanmar [Tanasevitch, 2017].

\section{Linyphia chiridota (Thorell, 1895)}

NOTES. Originally, the species has been described from Burma (= Myanmar) as Erigone chiridota Thorell, 1895 [Thorell, 1895]; later it was provisional transferred to Linyphia Latreille, 1804 by Tanasevitch [2010].

DISTRIBUTION. Known only from the type locality, Tharrawaddy, Bago State in Myanmar [Thorell, 1895].

\section{Microbathyphantes palmarius (Marples, 1955)}

DISTRIBUTION. Sri Lanka, India, Seychelles, Micronesia, Polynesia [World Spider Catalog, 2018] and northern Thailand [Tanasevitch, 2014b]. In Myanmar M. palmarius known from Rangoon, Yangon State [Helsdingen, 1985].

\section{Nasoona asocialis (Wunderlich, 1974)}

DISTRIBUTION. Nepal, NE India [Wunderlich, 1974, Tanasevitch, 1998; 2011, as Gorbothorax aff. ungibbus Tanasevitch, 1998], Laos, Thailand, West Malaysia and Indonesia [Tanasevitch, 2014a, 2017]. In Myanmar N. asocialis known from Mandalay Region: Anisakan (600 m a.s.1.); National Kandawgyi Botanical Gardens (1120 m a.s.l.), and from Pwe Kauk Falls (990 m a.s.1.) [Tanasevitch, 2017].

\section{Nasoona crucifera (Thorell, 1895)}

DISTRIBUTION. Laos [Tanasevitch, 2014a], Vietnam [Simon, 1909], southern China [Han, Zhu, 2008], Thailand, West Malaysia [Tanasevitch, 2014b], India, Singapore, East Malaysia and Indonesia [Tanasevitch, 2017]. In Myanmar N. crucifera known from Tharrawaddy, Bago State, [Thorell, 1895].

\section{Neriene birmanica (Thorell, 1887)}

DISTRIBUTION. India, Kashmir, Myanmar, Laos, China, Indonesia (Bali) [World Spider Catalog, 2018]. In Myanmar N. birmanica known from Moulmein, Mon State [Thorell, 1887].

\section{Neriene macella (Thorell, 1898)}

DISTRIBUTION. Laos [Tanasevitch, 2014a], Thailand [Tanasevitch, 2014b], China [Chen et al., 1995], Sumatra, Indonesia [Simon, 1901], West Malaysia [Locket, 1982], India and the Philippines [Tanasevitch, 2017]. In Myanmar N. macella known from Bhamò, Kachin State [Thorell, 1898].
Oedothorax myanmar Tanasevitch, 2017

DISTRIBUTION. Known only from the type locality, Kampetlet (1585 m a.s.1), Chin State, Myanmar [Tanasevitch, 2017].

ACKNOWLEDGEMENTS. I am greatly indebted to Peter Jäger and Julia Altmann (SMF) for the access to the spider collection under their care. I also thank Sergei I. Golovatch (Moscow) who kindly checked the English of an advanced draft.

\section{References}

Chen J., Li. S.Q., Zhao J.X. 1995. A new record of spider of the genus Neriene from China (Araneae: Linyphiidae) // Acta Arachnologica Sinica. Vol.4. P.137-139.

Han G.X., Zhu M.S. 2008. One new record species of the genus Nasoona from China (Arachnida: Araneae: Erigoninae) // Journal of Hebei University, Natural Science Edition. Vol.28. P.206208.

Helsdingen P.J., van. 1985. Araneae: Linyphiidae of Sri Lanka, with a note on Erigonidae // Entomologica Scandinavica (Suppl.). Vol.30. P.13-30.

Hormiga G. 2000. Higher level phylogenetics of erigonine spiders (Araneae, Linyphiidae, Erigoninae) // Smithsonian Contributions to Zoology. No.609. P.1-160.

Locket G.H. 1982. Some linyphiid spiders from western Malaysia // Bulletin of the British arachnological Society. Vol.5. P.361384.

Merrett P. 1963. The palpus of male spiders of the family Linyphiidae // Proceedings of the Zoological Society of London. Vol.140. P.347-467.

Simon E. 1901. On the Arachnida collected during the Skeat expedition to the Malay Peninsula // Proceedings of the Zoological Society of London. T.71. No.1. P.45-84.

Simon E. 1909. Etude sur les arachnides du Tonkin (1re partie) // Bulletin Scientifique de la France et de la Belgique. T.42. P.69-147.

Tanasevitch A.V. 1998. Gorbothorax n. gen., a new linyphiid spider genus from the Nepal Himalayas (Arachnida, Araneae, Linyphiidae) // Bonner Zoologische Beiträge. Bd.47. S.421428.

Tanasevitch A.V. 2010. A revision of the Erigone species described by $\mathrm{T}$. Thorell from Burma (Aranei: Linyphiidae) // Arthropoda Selecta. Vol.19. No.2. P.103-107.

Tanasevitch A.V. 2011. Linyphiid spiders (Araneae, Linyphiidae) from Pakistan and India // Revue Suisse de Zoologie. Vol.118. No.3. P.561-598.

Tanasevitch A.V. 2014a. New species and records of linyphiid spiders from Laos (Araneae, Linyphiidae) // Zootaxa. No.3841. No.1. P.67-89.

Tanasevitch A.V. 2014b. On the linyphiid spiders from Thailand and West Malaysia (Arachnida: Aranei: Linyphiidae) // Arthropoda Selecta. Vol.23. No.4. P.393-414.

Tanasevitch A.V. 2015. Notes on the spider genus Oedothorax Bertkau, 1883 with description of eleven new species from India (Linyphiidae: Erigoninae) // Revue suisse de Zoologie. T.122. Fasc.2. P.381-398.

Tanasevitch A.V. 2017. New species and new records of linyphiid spiders from the Indo-Malayan Region (Araneae, Linyphiidae) // Zootaxa. No.4227(3). P.325-346.

Thorell T. 1887. Viaggio di L. Fea in Birmania e regioni vicine. II. Primo saggio sui ragni birmani // Annali del Museo Civico di Storia Naturale di Genova. Vol.25. P.5-417.

Thorell T. 1895. Descriptive catalogue of the spiders of Burma. London. 406 pp.

Thorell T. 1898. Viaggio di Leonardo Fea in Birmania e regioni vicine. LXXX. Secondo saggio sui Ragni birmani. II. Retite- 
lariae et Orbitelariae // Annali del Museo Civico di Storia Naturale di Genova. Vol.2. No.19. P.271-378.

Tu L.H., Li S.Q. 2005. A new species of the genus Hylyphantes (Araneae: Linyphiidae) from Sichuan Province, China // Acta zootaxonomica sinica. Vol.30. P.62-64.

World Spider Catalog 2018. World Spider Catalog, version 18.5

Natural History Museum Bern. Online at http://wsc.nmbe.ch (accessed in April, 2018).
Wunderlich J. 1974. Linyphiidae aus Nepal, II. Die Gattung Oedothorax Bertkau 1883 (Arachnida: Araneae) // Senckenbergiana Biologica. Bd.55. S.169-188.

Responsible editor K.G. Mikhailov 